\title{
Habitat suitability and connectivity inform a co-management policy of protected area network for Asian elephants in China
}

\author{
Cheng Huang ${ }^{1,2}$, Xueyou Li $^{1}{ }^{,}$Laxman Khanal $^{3}$, Xuelong Jiang ${ }^{\text {Corresp. } 1}$ \\ ${ }^{1}$ Kunming Institute of Zoology, Chinese Academy of Sciences, Kunming, China \\ 2 Kunming College of Life Sciences, University of Chinese Academy of Sciences, Kunming, China \\ 3 Central Department of Zoology, Institute of Science and Technology, Tribhuvan University, Kathmandu, Nepal \\ Corresponding Author: Xuelong Jiang \\ Email address: jiangxl@mail.kiz.ac.cn
}

Enlarging protected area network (PAN) is critical to ensure long-term population viability of Asian elephants (Elephas maximus), which are threatened by habitat loss and fragmentation. Strict policies of PAN enlargement that focus on wildlife conservation have failed largely due to difficulties in encouraging stakeholder participation and meeting elephant habitat requirement. A co-management policy that promotes sustainable resource use, wildlife conservation, and stakeholder participation may have greater feasibility than the strict policies in a developing world. Here, we identified suitable habitat of elephants using maximum entropy models (MaxEnt) and examined whether habitat suitability is indirectly associated with local economic development in human-dominated landscapes. We found that (1) the suitable habitat was mainly in areas of forest matrix ( $50 \%$ natural forest cover) with multiple land-use practices rather than relatively intact forest and near communities (mean distance $2 \mathrm{~km}$ ) and (2) habitat suitability was negatively associated with local economic development $\left(r_{\mathrm{P}}=-0.37, P=0.04\right)$. From the standpoint of elephant habitat and its socio-economic background, our results indicate that co-management will be more effective than the currently strict approaches of enlarging PAN. Additionally, our results provide on-ground information for elephant corridor design in southern China. 
1 Habitat suitability and connectivity inform a co-

2 management policy of protected area network for

3 Asian elephants in China

4

5

6

7

8

\section{9}

10

11

12

13

14

15

16

17

18

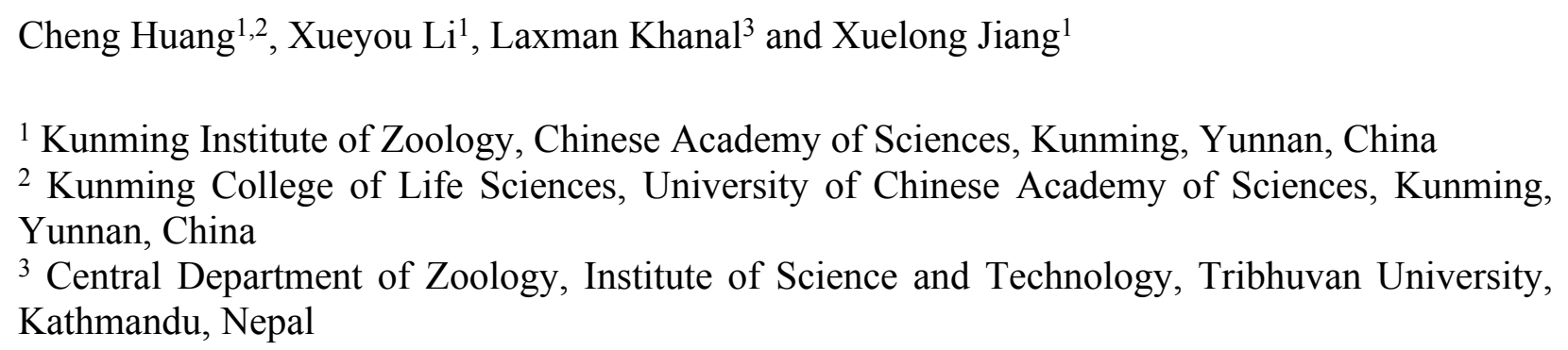

\section{ABSTRACT}

Enlarging protected area network (PAN) is critical to ensure long-term population viability of Asian elephants (Elephas maximus), which $\overline{\overline{\bar{a}}}$ threatened by habitat loss and fragmentation. Strict policies of PAN enlargement that focus on wildlife conservation have failed largely due to difficulties in encouraging stakeholder participation and meeting elephant habitat requirement. A co-management policy that promotes sustainable resource use, wildlife conservation, and stakeholder participation may have greater feasibility than the strict policies in a developing world. Here, we identified suitable habitat of elephants using maximum entropy models (MaxEnt) and examined whether habitat suitability is indirectly associated with local economic development in human-dominated landscapes. We found that (1) the suitable habitat was mainly in areas of forest matrix ( $50 \%$ natural forest cover) with multiple land-use practices rather than relatively intact forest and near communities (mean distance $2 \mathrm{~km}$ ) and (2) habitat suitability was negatively associated with local economic development $\left(r_{\mathrm{P}}=-0.37, P=0.04\right)$. From the standpoint of elephant habitat and its socio-economic background, our results indicate that comanagement will be more effective than the currently strict approaches of enlarging PAN. Additionally, our results provide on-ground information for elephant corridor design in southern China.

\section{INTRODUCTION}

Protected area networks (PANs) typically comprise core protected areas (PAs) and corridors that are the cornerstones for ensuring long-term population viability of wildlife by safeguarding contiguous habitat (Wilson \& MacArthur, 1967, Bennett \& Mulongoy, 2006, Geldmann et al., 2013). Although PAN coverage was markedly increased over the past century with $15 \%$ of 
41 global land protected in 2018 (https://livereport.protectedplanet.net/chapter-2), some half of PAs 42 were established primarily for preserving natural ecosystem similar to PAs of IUCN categories

43 I-IV, i.e., nature reserve (NR), wilderness area, national park, natural monument, and

44 habitat/species management area (McDonald \& Boucher, 2011), where human activities are 45 strictly restricted. These strict policies generate three concerns from conservation fields. First, 46 the habitat suitability of some species and taxa in strict PAs might be decreased over time due to 47 lack of landscape heterogeneity (Wharton, 1968, Mudappa et al., 2007, Evans et al., 2018).

48 Second, PA-oriented efforts lead to increased isolation of PAs and wide-ranged species (DeFries 49 et al., 2005, Laurance et al., 2012) because primary and secondary vegetation in human50 dominated landscapes are continually eroded (Joppa \& Pfaff, 2009, Acharya et al., 2017, Evans 51 et al., 2018). Third, encouraging local stakeholder participation is difficult especially in 52 developing countries because the establishment of strict PAs and economic development are 53 commonly regarded as competing issues by local stakeholders (Bennett \& Mulongoy, 2006, 54 McDonald \& Boucher, 2011). In this context, a co-management policy that promotes sustainable 55 resource use, wildlife conservation, and stakeholder participation potentially provides a more feasible mean for PAN enlargement for some species or taxa in human-dominated landscapes (Zhang et al., 2006, Goswami et al., 2014, Evans et al., 2018).

Several global biodiversity hotspots are found in south and southeast Asia (Myers et al., 2000), where wildlife is threatened by human activities (e.g., agriculture and infrastructure) (Ceballos \& Ehrlich, 2002, Edwards et al., 2010, Hansen et al., 2013, Clements et al., 2014). Large animals are particularly affected because of their wide range (Ceballos \& Ehrlich, 2002; Robert et al., 2006) and negative interactions with villagers (Acharya et al., 2017, AsERSM, 2017). Although Asian elephants (Elephas maximus) are endangered species and are important in ecosystem function (e.g., seed dispersal and nutrient recycling), culture, and fundraising for wildlife conservation (Campos-Arceiz et al., 2008; Ritchie \& Johnson, 2009; Verissimo et al., 2011), only $29 \%$ of their distribution range is legally protected in 13 countries (Hedges et al., 2008), and most is in human-dominated landscapes (Jathanna et al., 2015, Calabrese et al., 2017). Enlarging PAN was suggested as a priority for their conservation (AsERSM, 2017). However, today, economic development is the top priority in many regions, and thus attempts to expand PAN with the strict policies is likely to fail socially (Bennett \& Mulongoy 2006, Zhang et al., 2006, Evans et al., 2018).

Strict PAN might also be failed to meet the elephant habitat requirement. Asian elephants are habitat generalists that use primary and secondary forests, scrubland, grassland, and farmland (Choudhury et al., 2008), and their resource-use and safety strategies are context-dependent. For instance, in China, the Cangyuan population (20-23 individuals) tend to stay within an area of $\sim 33 \mathrm{~km}^{2}$ in an NR (Liu et al., 2016); the Mengla-Shangyong population (88-98 individuals) is located within two subdivisions (1 $239 \mathrm{~km}^{2}$ ) of an NR and its periphery (Chen et al., 2013); the Menghai-Lancang population (15 individuals) and most of the Xishuangbanna-Pu'er population (98-109 individuals) frequently use human-dominated landscapes (Fig. 1). Despite these differences, there is mounting evidence that Asian elephants are forest-edge specialists at the fine 
81 spatial scale (Sitompul et al., 2013; Wadey et al., 2018). However, strict PAN substantially

82 reduces human resource use and fire incidence (Nelson \& Chomitz, 2011), resulting in intact

83 closed forests, which are less suitable for elephants than moderately disturbed forests (Sitompul

84 et al., 2013, Evans et al., 2018, Wadey et al., 2018).

85 On the other hand, elephants cause extensive damage to villages by raiding crops, damaging

86 property, and even killing people (Gubbi, 2012, Chen et al., 2016). Areas with severe damage or

87 frequently used by Asian elephants are typified by hilly terrain with traditional farming practices

88 and relatively far from major roads (Wilson et al., 2013, Chen et al., 2016). Villages in these

89 areas are generally less developed economically than villages located in areas with flat terrain

90 and large cash-crop plantations near major roads. Thus, alternative supports to these villages are

91 necessary to offset elephant-caused losses and encourage villager participation in enlarging PAN

92 for elephants.

93 Here, we propose that a co-management policy that integrates sustainable resource use, wildlife

94 conservation, and stakeholder participation is more feasible than the currently strict policies that

95 only focus on wildlife conservation. This proposition will be supported by two key pieces of

96 evidence. First, areas of relatively intact forest are less suitable for elephants than forest matrix

97 with multiple land-use practices. Second, habitat suitability is negatively associated with local

98 economic development; namely, areas of poorer villages provide more suitable habitat than areas

99 of relatively wealthy villages. Our study provides useful information to guide conservation

100 policy to improve PAN enlargement and corridor design for elephant conservation.

101 MATERIALS \& METHODS

102 Field permit

103 Field studies were conducted under the permission from the Yunnan Forestry and Grassland

104 Administration.

\section{Study area}

106 This study was conducted within the range of the Xishuangbanna-Pu'er population in

107 Xishuangbanna and Pu'er, Yunnan, southwest China, bordering Vietnam and Laos (Fig. 1). This

108 population comprises five subpopulations, i.e., Liushun, Yunxian, Simaogang, Jiangcheng, and

109 Mengyang (Fig. 1). The region ranges from $495 \mathrm{~m}$ to $1851 \mathrm{~m}$ above sea level, with an annual

110 mean temperature of $21^{\circ} \mathrm{C}$ and annual precipitation of $\sim 1500 \mathrm{~mm}$ (Liu et al., 2018). Natural

111 forests (mainly subtropical evergreen broad-leaved forest) are fragmented by production forests

112 (e.g., Pinus kesiya and Eucalyptus spp.), cash-crop plantations (e.g., rubber, coffee, and tea), and

113 traditional farmlands (e.g., corn, rice, and sugarcane) (Chen et al., 2010). Three corridors (I, II,

114 and III) were proposed by Zhang et al. (2015) to connect the (a) Menghai-Lancang and

115 Xishuangbanna-Pu'er population and (b) subpopulations of the Xishuangbanna-Pu'er population

116 (Fig. 1). However, the Jinghong hydro-power dam raised the water level of the Mekong River,

117 isolating the Menghai-Lancang population from the Xishuangbanna-Pu'er since 2005 (Chen et

118 al., 2010). The study area includes 32 villages, each of which comprises several communities

119 (251 in total). A town is the social center of villages and usually comprises several adjacent

120 communities. The primary industries are agriculture and agroforestry (Chen et al., 2010).

Peer) reviewing PDF | (2018:11:33037:3:0:NEW 10 Mar 2019) 


\section{Data collection}

122 In the confirmed range, we collected data on elephant presence and land-cover along 91 line

123

124

125

126

127

128

129

130

131

132

133

134

135

136

137

138

139

140

141

142

143

144

145

146

147

148

149

150

151

152

153

154

155

156

157

158

159

160 transects $(307 \mathrm{~km}$ ) from December 2016 and March 2017, with the assistance of forest rangers. These line transects were designed to traverse all land-cover types (Fig. 1 and 2). Dung piles and footprints within a $20 \mathrm{~m}$ width of the line transects were recorded, with intervals of at least 200 $\mathrm{m}$ (Dataset S1). Land-cover was categorized into seven types: i.e., natural forest, pine plantation (i.e., Pinus kesiya), cash-crop plantation, shrubland, traditional farmland, infrastructure site (e.g., settlements and roads), and water body (i.e., rivers, reservoirs, and ponds) (Chen et al., 2010). We treated the per-capita annual income of village as a proxy for economic development, with higher incomes representing higher levels of economic development. The data was collected from the Digital Village of Yunnan (http://www.ynszxc.gov.cn/).

\section{Data analysis}

The analysis included five steps. First, environmental variables were selected for habitat suitability models. Second, a land-cover map was developed from remote-sensing images. Third, maximum entropy models (MaxEnt) were used to identify suitable habitat of elephants. Fourth, the elephant pathways were simulated by least-cost and circuit models. Fifth, the potential negative association between habitat suitability and level of economic development was examined by Pearson's correlation.

\section{Environmental variables}

Asian elephants frequently occur in areas of low altitude, flat terrain, and low human disturbance and feed on natural foods or crops near forest edge (Jathanna et al., 2015, Lin et al., 2015, Liu et al., 2016). Hence, we selected thirteen environmental variables in three categories for habitat suitability models (Table 1): i.e., geographic and topographic (altitude and terrain roughness index), land-cover (distance to, edge density of, and percentage of natural forest, pine plantation, and traditional farmland), and human disturbance (distance to town and distance to community).

\section{Land-cover classification}

We used Landsat 8 OLI_TIRS images (30-m resolution from the Data Cloud of CAS, http://www.csdb.cn/) to develop a land-cover map. We added ancillary layers to improve classification accuracy, including ASTER GDEM grids (the Data Cloud of CAS), slope and its texture, and Normalized Difference Vegetation Index and its texture (Wegmann et al., 2016). We performed a supervised classification using the random forest algorithm with $25 \%$ of land-cover points left to validate the classification (Leutner \& Horning, 2017).

\section{MaxEnt modeling}

For habitat suitability models with presence-only data, MaxEnt outperforms other existing approaches (Ferrier et al., 2006, Phillips et al., 2006). MaxEnt contrasts environment of wildlife presences against the available background (Elith et al., 2011). Here, the background was represented by 10000 points randomly generated in buffer zones of average home range size $\left(113 \mathrm{~km}^{2}\right)$ around the presence points (Dataset S2) (Fernando et al., 2008; Amirkhiz et al., 2018). To identify important environmental variables describing habitat suitability and build a model with high accuracy, we performed an optimized selection of variables and MaxEnt features and $\beta$ 
161 multiplier based on Akaike information criteria (AIC) following the workflow of Amirkhiz et al.

162 (2018). First, each model included variables that were not highly correlated $((|r| \leqslant 0.7)$ and that 163 had a model contribution $>5 \%$ and then step-wise optimized the $\beta$ multiplier from 0 to 15 at an 164 increment of 0.5 . Second, as MaxEnt calculates five models for each variable, known as features 165 (i.e., linear (L), quadratic (Q), product (P), threshold (T), and hinge (H))(Phillips et al., 2017), we 166 selected feature sets by the lowest AIC among "L", "H", "LQ", "LQT", "LP", "HP", "LQP", and 167 "LQTP", then used the optimized model to predict a habitat suitability map. The prediction was

168

169

170

171

172

173

174

175

176

177

178

179

180

181

182

183

184

185

186

187

188

189

190

191

192

193

194

195

196

197

198

199

200 evaluated by threshold-independent (Area Under the Curve of the Receiver Operating Characteristic plot, AUC) and threshold-dependent omission rate. Third, a 10\% training presence threshold was used for delineating the suitable from unsuitable habitat (Escalante et al., 2013, Hughes, 2017), after which we summarized the characteristics of the suitable habitat. The modeling was performed in $\mathrm{R}$ with MaxentVariableSelection and ENMeval package (Team 2013, Muscarella et al., 2014, Jueterbock, 2016).

\section{Pathway mapping}

Least-cost and circuit models are two widely used approaches for animal corridor design (RuizGonzález et al., 2014, Wang et al., 2014). We simulated the elephant pathways by least-cost and circuit models using Linkage Mapper and Circuitscape software (McRae \& Shah, 2009; Wang et al., 2014; Mcrae et al., 2008), in which the length and resistance of the least-cost paths were calculated. The resistance surface was calculated by one minus the habitat suitability layer. As we focused on mapping pathways around the previously-proposed corridors (I, II, and III) by Zhang et al. (2015), the least-cost model was constructed with three core ranges, i.e., Mengyang, Liushun and Simaogang, and Jiangcheng (Fig. 1). All presence points were used to produce a connectivity map for the entire study area by circuit model.

\section{Association between habitat suitability and level of economic development}

In the study area, economic development of a village is a consequence of its altitude, terrain, and land-use practices and thus may be indirectly associated with habitat suitability of the elephants. The habitat suitability of a village was calculated by averaging that of communities, which were extracted from the habitat suitability map by community locations. We used Pearson's correlation to examine the direction and significance of the association between habitat suitability and level of economic development.

\section{RESULTS}

We collected 245 presence points of Asian elephants. The overall accuracy of the land-cover map was 0.91 . The model with the lowest AIC had a $\beta$ multiplier=1; LQTP features; and eight variables, including terrain roughness index, distance to town, community settlement, natural forests, and traditional farmlands, and percentage of natural forest, pine plantation, and traditional farmland. The percentage of natural forests $(23 \%)$, distance to town $(23 \%)$, and distance to community $(16 \%)$ were among the strongest predictors of the elephant presence. In general, the optimized model accurately discriminated the presence points from the background environment (mean $\mathrm{AUC}=0.86$ ). The low AUC difference (0.05) suggested that the model did not over-fit the presence points. Threshold-dependent measures indicated that the 
201 model had low over-fitting and high discriminatory ability at $10 \%$ omission rate $(0.20)$ and 202 lowest presence threshold $(<0.001)$. The threshold value of the suitable habitat was 0.28 . In our 203 study, the suitable habitat of Asian elephants was mainly found in areas of forest matrix $(50 \%$ 204 natural forest cover) with multiple land-use practices rather than relatively intact forest, away 205 from towns (mean distance $10 \mathrm{~km}$ ), near communities (mean distance $2 \mathrm{~km}$ ), and with flat terrain 206 (mean terrain roughness index 4.83) (Fig. 2).

207 The least-cost model (Fig. 3) demonstrated that the shortest pathway is \#3 $(29 \mathrm{~km})$ and the 208 longest pathway is \#2 $(47 \mathrm{~km})$, while pathway \#1 had the lowest habitat resistance. The 209 connectivity map of the study area supported pathway \#1 as a potential corridor to connect the 210 Mengyang and Jiangcheng subpopulation (Fig. 3). Additionally, the connectivity map showed 211 that the area of the white rectangle on Fig. 3 is important in connecting the subpopulations of

212 Mengyang to Liushun and Simaogang because of its location and relatively high habitat 213 connectivity.

214 There was a significant negative correlation between the habitat suitability of elephants and the 215 level of economic development $\left(r_{\mathrm{P}}=-0.37, P=0.04\right)$. Thus, areas of peorer villoges provided 216 more suitable habitat than areas of relativaly wanlthry willages;

\section{DISCUSSION}

218 For elephants, habitat selection reflects a trade-off between resource use and mortality risk 219 (Munshi-South et al., 2008, Basille et al., 2009). Here, natural forest was the strongest variable 220 influencing the presence of Asian elephants (as elsewhere, Liu et al. 2016) and indicates the 221 substantial role natural forest has for the elephants with respect to food, refuge and 222 thermoregulation (Kumar et al., 2010, Goswami et al., 2014, Evans et al., 2018). In particular, 223 forest matrix (50\% natural forest cover) with multiple land-use practices are more suitable for the 224 elephants than relatively intact forest in human-dominated landscapes (Sitompul et al., 2013, 225 Evans et al., 2018, Wadey et al., 2018). Forest edges provide better light conditions for Ficus 226 spp. and grasses that are primary natural foods of elephants (Chen et al., 2006, Sitompul et al., 227 2013, Wadey et al., 2018). Also, crops in the forest matrix are attractive to the elephants, with $22868 \%$ of feeding sites in such areas during the rainy season (Zhang et al., 2003). On the other 229 hand, elephants suffer mortality at the hands of humans, both directly and indirectly, from ditch, 230 electrocution, and retaliatory killing (Chen et al., 2013; Palei et al., 2014; AsERSM, 2017). As a 231 consequence, Asian elephants are less likely to occur near towns with dense human population, 232 infrastructure, and plantation (Fig. 2). Although we focused on habitat suitability patterns of the 233 elephants in human-dominated landscapes, similar patterns can be found in NRs and their 234 peripheries. For example, the Mengla-Shangyong population mostly inhabits the buffer and 235 experimental zones of an NR and its peripheries with moderately disturbed landscapes (Fig. 1) 236 (Hongpei Yang pers. comm.).

237 Based on the quantitative analysis, efforts on establishing corridors for the elephants should be 238 concentrated on the predicted pathways and areas of high connectivity. With the greatest length 239 and largest movement resistance, pathway \#2 was rarely used by the elephants (based on long240 term monitoring of Chen et al. (2010) and Zhang et al. (2015)). Despite having the shortest 
241 length, the resistance of pathway \#3 was only slightly less than that of pathway \#2 and traversed

242 tracts of rubber plantations (Fig. 2), where stakeholders are unlikely to restore contiguous natural

243 habitat for the elephants. Pathway \#1 was the most consistent with the connectivity map

244 calculated by the circuit model and had the lowest resistance. Thus, pathway \#1 should be

245 allocated greater conservation priority than pathway \#2 and \#3. Also, efforts are needed to

246 protect the connective habitat of the area with the white rectangle on Fig. 3. Our study provides

247 more precise information for elephant corridor design than Zhang et al. (2015).

248 Habitat suitability of Asian elephants is affected by many factors. Our study is limited by our

249

250

251

252

253

254

255

256

257

258

259

260

261

262

263

264

265

266

267

268

269

270

271

272

273

274

275

276

277

278

279

280 reliance on presence-only data and variables extracted from remote sensing images to determine the habitat suitability, from which the resistance layer was generated for simulating pathways. Incorporating movement data of elephants recorded by telemetry techniques and on-ground variables (e.g., food abundance and forest structure) could improve habitat suitability models and provide straightforward movement trajectories for corridor design.

In China, PANs include NRs ( $\sim 15 \%$ of the national territory), world natural and cultural heritage sites, scenic zones, wetland parks, forest parks, geological parks, and water conservancy scenic locations (Cao et al., 2015). While most NRs are managed as socially exclusive landscapes (Zhang et al., 2006, Cao et al., 2015), including the Xishuangbanna National Nature Reserve (soft green area in Fig. 1), Asian elephants need forest matrix with open lands and are flexible to human disturbance. Conservation policies allowing considerable interventions in NRs could enlarge elephant habitat without great loss of biodiversity. For example, selectively logged forests appear to maintain $\sim 90 \%$ of the original biodiversity compared to primary forest (Berry et al., 2010, Brodie et al., 2014), and retention forestry, whereby a proportion of original vegetation is left unlogged, further reduces the negative impacts on biodiversity (Gaveau et al., 2013, Fedrowitz et al., 2014). Among NRs, efforts should be paid to protect community-owned forests, which represent a major proportion of natural forests and are critical for elephants (Kumar et al., 2010, Evans et al., 2018) and other wildlife (Rodrigues et al., 2017, Rodrigues \& Chiarello, 2018). Meanwhile, integrating traditional farmlands into PANs can fulfill human needs and encourage the participation of villagers. Generally, the less-developed villages are more suitable to the elephants than are the more-developed villages. Thus, supporting sustainable economic development and reducing elephant-caused losses are needed to encourage human-elephant coexistence, and may include developing ecotourism, encouraging wildlife-friendly products, and compensating the losses (Mishra et al., 2003; Chen et al., 2013; Huang et al., 2018).

\section{CONCLUSIONS}

Asian elephants are globally threatened by habitat fragmentation and loss. Thus, enlarging PANs is the current priority for elephant conservation (AsERSM, 2017). Using presence data from an on-ground survey in human-dominated landscapes combined with habitat suitability models, we found that: (1) suitable habitat of the elephants was mainly in areas of forest matrix with multiple land-use practices rather than relatively intact forests and near communities; and (2) habitat suitability and level of economic development had an inverse correlation. From the standpoint of the elephant habitat and its socio-economic background, our results suggest that a co- 
281

282

283

284

285

286

287

288

289

290

291

292

293

294

295

296

297

298

299

300

301

302

303

304

305

306

307

308

309

310

311

312

313

314

315

316

317

318

319

320

management policy would be more feasible than the currently strict policies for enlarging PANs. Such a policy would also be suitable for other areas with similar land-cover practices and socioeconomic contexts, such as northeastern India and northern Laos (Kumar et al., 2010, Wilson et al., 2013, AsERSM, 2017).

\section{ACKNOWLEDGEMENTS}

We are grateful to the Pu'er Forestry Bureau, Xishuangbanna National Nature Reserve, and Jinghong Forestry Bureau for field support. We thank Hongpei Yang and Wei Cha for sharing their experiences, and Zhonghua Li, Li He, and Dan Yan for their assistance in the field.

\section{REFERENCES}

Acharya, K.P., Paudel, P.K., Jnawali, S.R., Neupane, P.R., Koehl, M., 2017. Can forest fragmentation and configuration work as indicators of human-wildlife conflict? Evidences from human death and injury by wildlife attacks in Nepal. Ecol. Indic. 80, 74-83.

Adams, W.M., Aveling, R., Brockington, D., Dickson, B., Elliott, J., Hutton, J., Roe, D., Vira, B., Wolmer, W., 2004. Biodiversity conservation and the eradication of poverty. Science. $306,1146-1149$.

Amirkhiz, G.R., Frey, J.K., Cain Iii, J.W., Breck, S.W., Bergman, D.L., 2018. Predicting spatial factors associated with cattle depredations by the Mexican wolf (Canis lupus baileyi) with recommendations for depredation risk modeling. Biol. Conserv. 224, 327-335.

AsERSM, 2017. Report: Asian elephant range states meeting. Jakarta, Indonesia. Retrieved from https://elephantconservation.org/iefImages/2018/03/AsERSM-2017_Final-Report.pdf.

Basille, M., Herfindal, I., Santin-Janin, H., Linnell, J.D.C., Odden, J., Andersen, R., Arild Høgda, K., Gaillard, J.M., 2009. What shapes Eurasian lynx distribution in human dominated landscapes: selecting prey or avoiding people? Ecography. 32, 683-691.

Bennett, G., Mulongoy, K.J., 2006. Review of experience with ecological networks, corridors and buffer zones, in: Secretariat of the Convention on Biological Diversity, Montreal, Technical Series 23:5-6.

Berry, N.J., Phillips, O.L., Lewis, S.L., Hill, J.K., Edwards, D.P., Tawatao, N.B., Ahmad, N., Magintan, D., Khen, C. V, Maryati, M., Ong, R.C., Hamer, K.C., 2010. The high value of logged tropical forests: lessons from northern Borneo. Biodivers. Conserv. 19, 985-997.

Brodie, J.F., Giordano, A.J., Zipkin, E.F., Bernard, H., Mohd-azlan, J., Ambu, L., 2014. Correlation and persistence of hunting and logging impacts on tropical rainforest mammals. Conserv. Biol. 29, 110-121.

Calabrese, A., Calabrese, J.M., Songer, M., Wegmann, M., Hedges, S., Rose, R., Leimgruber, P., 2017. Conservation status of Asian elephants: the influence of habitat and governance. Biodivers. Conserv. 26, 2067-2081.

Campos-Arceiz, A., Larrinaga, A.R., Weerasinghe, U.R., Takatsuki, S., Pastorini, J., Leimgruber, P., Fernando, P., Santamaria, L., 2008. Behavior rather than diet mediates seasonal difference in seed dispersal by Asian elephants. Ecology 89, 2684-2691. 
321

322

323

324

325

326

327

328

329

330

331

332

333

334

335

336

337

338

339

340

341

342

343

344

345

346

347

348

349

350

351

352

353

354

355

356

357

358

359

360

Cao, M., Peng, L., Liu, S., 2015. Analysis of the network of protected areas in China based on a geographic perspective: Current status, issues and integration. Sustain. 7, 15617-15631.

Ceballos, G., Ehrlich, P.R., 2002. Mammal population losses and the extinction crisis. Science. 296, 904-907.

Chen, J., Deng, X., Zhang, L., Bai, Z., 2006. Diet composition and foraging ecology of Asian elephants in Shangyong, Xishuangbanna, China. Acta Ecol. Sin. 26, 309-316.

Chen, M., Hong, G., Li, Z., Dong, Y., Yang, Y., 2013. Studies of conflict between elephant and human being in China. Yunnan Science and Technology Press, Kunming, Yunnan, China.

Chen, M., Li, Z., Guo, X., Yang, Z., Dong, Y., 2010. Asian elephant conservation corridors in China. Yunnan Science and Technology Press, Kunming, Yunnan, China.

Chen, S., Yi, Z., Campos-Arceiz, A., Chen, M., Webb, E.L., 2013. Developing a spatiallyexplicit, sustainable and risk-based insurance scheme to mitigate human-wildlife conflict. Biol. Conserv. 168, 31-39.

Chen, Y., Marino, J., Chen, Y., Tao, Q., Sullivan, C.D., Shi, K., Macdonald, D.W., 2016. Predicting hotspots of human-elephant conflict to inform mitigation strategies in Xishuangbanna, Southwest China. PLoS One 11, e0162035.

Choudhury, A.L., Choudhury, D.K., Desai, A., Duckworth, J.W., Easa, P.S., Johnsingh, A.J.T., Fernando, P., Hedges, S., Gunawardena, M., Kurt, F., 2008. Elephas maximus. IUCN Red List of Threatened Species.

Clements, G.R., Lynam, A.J., Gaveau, D., Yap, W.L., Lhota, S., Goosem, M., Laurance, S., Laurance, W.F., 2014. Where and how are roads endangering mammals in Southeast Asia's forests? PLoS One 9, 1-25.

DeFries, R., Hansen, A., Newton, A.C., Hansen, M.C., 2005. Increasing isolation of protected areas in tropical forests over the past twenty years. Ecol. Appl. 15, 19-26.

Desai, A.A., Riddle, H.S., 2015. Human-elephant conflict in Asia. United State Fish and Wildlife Service. Retrieved from https://www.fws.gov/international/pdf/Human-Elephant-Conflictin-Asia-June2015.pdf.

Edwards, D.P., Hodgson, J.A., Hamer, K.C., Mitchell, S.L., Ahmad, A.H., Cornell, S.J., Wilcove, D.S., 2010. Wildlife-friendly oil palm plantations fail to protect biodiversity effectively. Conserv. Lett. 3, 236 - 242.

Elith, J., Phillips, S.J., Hastie, T., Dudík, M., Chee, Y.E., Yates, C.J., 2011. A statistical explanation of MaxEnt for ecologists. Divers. Distrib. 17, 43-57.

Escalante, T., Rodríguez-Tapia, G., Linaje, M., Illoldi-Rangel, P., González-López, R., 2013. Identification of areas of endemism from species distribution models: threshold selection and Nearctic mammals. TIP 16, 5-17.

Evans, L.J., Asner, G.P., Goossens, B., 2018. Protected area management priorities crucial for the future of Bornean elephants. Biol. Conserv. 221, 365-373.

Fedrowitz, K., Koricheva, J., Baker, S.C., Lindenmayer, D.B., Palik, B., Rosenvald, R., Beese, W., Franklin, J.F., Kouki, J., Macdonald, E., 2014. Can retention forestry help conserve biodiversity? A meta-analysis. J. Appl. Ecol. 51, 1669-1679.

Peer) reviewing PDF | (2018:11:33037:3:0:NEW 10 Mar 2019) 
361

362

363

364

365

366

367

368

369

370

371

372

373

374

375

376

377

378

379

380

381

382

383

384

385

386

387

388

389

390

391

392

393

394

395

396

397

398

399

Fernando, P., Wikramanayake, E.D., Janaka, H.K., Jayasinghe, L.K.A., Gunawardena, M., Kotagama, S.W., Weerakoon, D., Pastorini, J., 2008. Ranging behavior of the Asian elephant in Sri Lanka. Mamm. Biol. 73, 2-13.

Ferrier, S., Guisan, A., Elith, J., Graham, C.H., Anderson, R.P., Dudı, M., Hijmans, R.J., Huettmann, F., Leathwick, J.R., Lehmann, A., Li, J., Lohmann, L.G., Loiselle, B.A., Manion, G., Moritz, C., Nakamura, M., Nakazawa, Y., Overton, J.M., Peterson, A.T., Phillips, S.J., Richardson, K., Scachetti-pereira, R., Schapire, R.E., Williams, S., Wisz, M.S., Zimmermann, N.E., 2006. Novel methods improve prediction of species , distributions from occurrence data. Ecography 29, 129-151.

Gaveau, D.L.A., Kshatriya, M., Sheil, D., Sloan, S., Molidena, E., Wijaya, A., Wich, S., Ancrenaz, M., Hansen, M., Broich, M., Guariguata, M.R., Pacheco, P., Potapov, P., Turubanova, S., Meijaard, E., 2013. Reconciling forest conservation and logging in Indonesian Borneo. PLoS One 8, e69887.

Geldmann, J., Barnes, M., Coad, L., Craigie, I.D., Hockings, M., Burgess, N.D., 2013. Effectiveness of terrestrial protected areas in reducing habitat loss and population declines. Biol. Conserv. 161, 230-238.

Goswami, V.R., Sridhara, S., Medhi, K., Williams, A.C., Chellam, R., Nichols, J.D., Oli, M.K., 2014. Community-managed forests and wildlife-friendly agriculture play a subsidiary but not substitutive role to protected areas for the endangered Asian elephant. Biol. Conserv. $177,74-81$.

Gubbi, S., 2012. Patterns and correlates of human-elephant conflict around a south Indian reserve. Biol. Conserv. 148, 88-95.

Hansen, M.C., Potapov, P. V, Moore, R., Hancher, M., Turubanova, Sa., Tyukavina, A., Thau, D., Stehman, S. V, Goetz, S.J., Loveland, T.R., 2013. High-resolution global maps of 21stcentury forest cover change. Science. 342, 850-853.

Hedges, S., Fisher, K., Rose, R., 2008. Range-wide mapping workshop for Asian elephants (Elephas maximus). Rep. to US Fish Wildl. Serv. Cambodia.

Huang, C., Li, X.Y., Shi, L.J., Jiang, X.L.. 2018. Patterns of human-wildlife conflict and compensation practices around Daxueshan Nature Reserve, China. Zool. Res. 39, 406-412.

Hughes, A.C., 2017. Mapping priorities for conservation in Southeast Asia. Biol. Conserv. 209, 395-405.

Jathanna, D., Karanth, K.U., Kumar, N.S., Karanth, K.K., Goswami, V.R., 2015. Patterns and determinants of habitat occupancy by the Asian elephant in the Western Ghats of Karnataka, India. PLoS One 10, e0133233.

Joppa, L.N., Pfaff, A., 2009. High and far: biases in the location of protected areas. PLoS One 4, e8273.

Jueterbock, A., Smolina, I., Coyer, J.A., Hoarau, G., 2016. The fate of the Arctic seaweed Fucus distichus under climate change: an ecological niche modeling approach. Ecol. Evol, 6, $1712-1724$. 
400 Kioko, J., Kiffner, C., Ndibalema, V., Hartnett, E., Seefeld, C., 2015. Maasai people and

401

402

403

404

405

406

407

408

409

410

411

412

413

414

415

416

417

418

419

420

421

422

423

424

425

426

427

428

429

430

431

432

433

434

435

436

437

438

439 elephants: values and perceptions. NISCAIR-CSIR, India.

Kumar, M.A., Mudappa, D., Raman, T.R.S., 2010. Asian elephant Elephas maximus habitat use and ranging in fragmented rainforest and plantations in the Anamalai Hills, India. Trop. Conserv. Sci. 3, 143-158.

Laurance W.F., Carolina Useche D., Rendeiro J., Kalka M, Bradshaw C.J.A., Sloan S.P., Laurance S.G., Campbell M., Abernethy K., Alvarez P., Arroyo-Rodriguez V., Ashton P., Benítez-Malvido J., Blom A., Bobo K.S., Cannon C.H., Cao M., Carroll R., Chapman C., Coates R., Cords M., Danielsen F., De Dijn B., Dinerstein E., Donnelly M.A., Edwards D., Edwards F., Farwig N., Fashing P., Forget P.M., Foster M., Gale G., Harris D., Harrison R., Hart J., Karpanty S., John Kress W., Krishnaswamy J., Logsdon W., Lovett J., Magnusson W., Maisels F., Marshall A.R., McClearn D., Mudappa D., Nielsen M.R., Pearson R., Pitman N., van der Ploeg J., Plumptre A., Poulsen J., Quesada M., Rainey H., Robinson D., Roetgers C., Rovero F., Scatena F., Schulze C., Sheil D., Struhsaker T., Terborgh J., Thomas D., Timm R., Nicolas Urbina-Cardona J., Vasudevan K., Joseph Wright S., Carlos Arias-G. J., Arroyo L., Ashton M., Auzel P., Babaasa D., Babweteera F., Baker P., Banki O., Bass M., Bila-Isia I., Blake S., Brockelman W., Brokaw N., Brühl C.A., Bunyavejchewin S., Chao J.T., Chave J., Chellam R., Clark C.J., Clavijo J., Congdon R., Corlett R., Dattaraja H.S., Dave C., Davies G., de Mello Beisiegel B., de Nazaré Paes da Silva R., Di Fiore A., Diesmos A., Dirzo R., Doran-Sheehy D., Eaton M., Emmons L., Estrada A., Ewango C., Fedigan L., Feer F., Fruth B., Giacalone Willis J., Goodale U., Goodman S., Guix J.C., Guthiga P., Haber W., Hamer K., Herbinger I., Hill J., Huang Z., Fang Sun I., Ickes K., Itoh A., Ivanauskas N., Jackes B., Janovec J., Janzen D., Jiangming M., Jin C., Jones T., Justiniano H., Kalko E., Kasangaki A., Killeen T., King H., Klop E., Knott C., Koné I., Kudavidanage E., Lahoz da Silva Ribeiro J., Lattke J., Laval R., Lawton R., Leal M., Leighton M., Lentino M., Leonel C., Lindsell J., Ling-Ling L., Eduard Linsenmair K., Losos E., Lugo A., Lwanga J., Mack A.L., Martins M., Scott McGraw W., McNab R., Montag L., Myers Thompson J., Nabe-Nielsen J., Nakagawa M., Nepal S., Norconk M., Novotny V., O’Donnell S., Opiang M., Ouboter P., Parker K., Parthasarathy N., Pisciotta K., Prawiradilaga D., Pringle C., Rajathurai S., Reichard U., Reinartz G., Renton K., Reynolds G., Reynolds V., Riley E., Rödel M.O., Rothman J., Round P., Sakai S., Sanaiotti T., Savini T., Schaab G., Seidensticker J., Siaka A., Silman M.R., Smith T.B., de Almeida S.S., Sodhi N., Stanford C., Stewart K., Stokes E., Stoner K.E., Sukumar R., Surbeck M., Tobler M., Tscharntke T., Turkalo A., Umapathy G., van Weerd M., Vega Rivera J., Venkataraman M., Venn L., Verea C., Volkmer de Castilho C., Waltert M., Wang B., Watts D., Weber W., West P., Whitacre D., Whitney K., Wilkie D., Williams S., Wright D.D., Wright P., Xiankai L., Yonzon P., Zamzani F. 2012. Averting biodiversity collapse in tropical forest protected areas. Nature 489, 290.

Leutner, B., Horning, N., 2017. RStoolbox: Tools for remote sensing data analysis. R package version 0.1.7. https://CRAN.R-project.org/package=RStoolbox. 
440

441

442

443

444

445

446

447

448

449

450

451

452

453

454

455

456

457

458

459

460

461

462

463

464

465

466

467

468

469

470

471

472

473

474

475

476

477

478

479

Lin, L., Jin, Y., Yang, H., Luo, A., Guo, X., Wang, L., Zhang, L., 2015. Evaluation of habitat for Asian elephants (Elephas maximus) in Xishuangbanna, Yunnan, China. Acta Theriol. Sin. 35, 2-13.

Liu, P., Hui, W., Liu, L., Jing, L., Li, Z., 2016. Habitat evaluation for Asian elephants (Elephas maximus) in Lincang: Conservation planning for an extremely small population of elephants in China. Biol. Conserv. 198, 113-121.

Liu, P., Wen, H., Harich, F.K., He, C., Wang, L., Guo, X., Zhao, J., Luo, A., Yang, H., Sun, X., Yu, Y., Zheng, S., Guo, J., Li, L., Zhang, L., 2017. Conflict between conservation and development: cash forest encroachment in Asian elephant distributions. Sci. Rep. 7, 6404.

Liu, S., Yin, Y., Li, J., Cheng, F., Dong, S., Zhang, Y., 2018. Using cross-scale landscape connectivity indices to identify key habitat resource patches for Asian elephants in Xishuangbanna, China. Landsc. Urban Plan. 171, 80-87.

McDonald, R.I., Boucher, T.M., 2011. Global development and the future of the protected area strategy. Biol. Conserv. 144, 383-392.

Mcrae, B.H., Dickson, B.G., Keitt, T.H., Shah, V.B., Mcrae, B.H., Dickson, B.G., Keitt, T.H., Shah, V.B., 2008. Using circuit theory to model connectivity in Ecology, Evolution, and Conservation. ECOLOGY 89, 2712-2724.

McRae, B.H., Shah, V.B., 2009. Circuitscape user's guide. Univ. California, St. Barbar.

Mishra, C., Allen, P., McCarthy, T., Madhusudan, M.D., Bayarjargal, A., Prins H.H.T., 2003. The role of incentive programs in conserving the snow leopard. Conserv. Biol. 17, 15121520 .

Mudappa, D., Noon, B.R., Kumar, A., Chellam, R., 2007. Responses of small carnivores to rainforest fragmentation in the southern Western Ghats, India. Small Carniv. Conserv. 36, $18-26$.

Munshi-South, J., Tchignoumba, L., Brown, J., Abbondanza, N., Maldonado, J.E., Henderson, A., Alonso, A., 2008. Physiological indicators of stress in African forest elephants (Loxodonta africana cyclotis) in relation to petroleum operations in Gabon, Central Africa. Divers. Distrib. 14, 995-1003.

Muscarella, R., Galante, P.J., Soley-Guardia, M., Boria, R.A., Kass, J.M., Uriarte, M., Anderson, R.P., 2014. ENMeval: An R package for conducting spatially independent evaluations and estimating optimal model complexity for ecological niche models. Methods Ecol. Evol. 5, 1198-1205.

Myers, N., Mittermeier, R.A., Mittermeier, C.G., Da, F.G., Kent, J., 2000. Biodiversity hotspots for conservation priorities. Nature 403, 853.

Palei, N.C., Palei, H.S., Rath, B.P., Kar, C.S., 2014. Mortality of the endangered Asian elephant Elephas maximus by electrocution in Odisha, India. Oryx 48,

Phillips, S.J., Anderson, R.P., Dudík, M., Schapire, R.E., Blair, M.E., 2017. Opening the black box: an open-source release of Maxent. Ecography 40, 887-893

Phillips, S.J., Anderson, R.P., Schapire, R.E., 2006. Maximum entropy modeling of species geographic distributions. Ecol. Modell. 190, 231-259.

Peer) reviewing PDF | (2018:11:33037:3:0:NEW 10 Mar 2019) 
480 R Development Core Team, 2013. R: A language and environment for statistical computing.

481

482

483

484

485

486

487

488

489

490

491

492

493

494

495

496

497

498

499

500

501

502

503

504

505

506

507

508

509

510

511

512

513

514

515

516

517

Vienna: R Foundation for Statistical Computing.

Ritchie, E.G., Johnson, C.N., 2009. Predator interactions, mesopredator release and biodiversity conservation. Ecol. Lett. 12, 982-998.

Robert, S., Wanlop, C., Naret, S., 2006. Collaborating to conserve large mammals in southeast Asia. Conserv. Biol. 20, 1391-1401.

Rodrigues, T.F., Chiarello, A.G., 2018. Native forests within and outside protected areas are key for nine-banded armadillo (Dasypus novemcinctus) occupancy in agricultural landscapes. Agric. Ecosyst. Environ. 266, 133-141.

Rodrigues, T.F., Kays, R., Parsons, A., Versiani, N.F., Paolino, R.M., Pasqualotto, N., Krepschi, V.G., Chiarello, A.G., 2017. Managed forest as habitat for gray brocket deer (Mazama gouazoubira) in agricultural landscapes of southeastern Brazil. J. Mammal. 98, 1301-1309.

Ruiz-González, A., Gurrutxaga, M., Cushman, S.A., Madeira, M.J., Randi, E., Gómez-Moliner, B.J., 2014. Landscape genetics for the empirical assessment of resistance surfaces: The European pine marten (Martes martes) as a target-species of a regional ecological network. PLoS One 9, e110552.

Sitompul, A.F., Griffin, C.R., Rayl, N.D., Fuller, T.K., 2013. Spatial and temporal habitat use of an Asian Elephant in Sumatra. Anim. an open access J. from MDPI 3, 670-679.

Verissimo, D., Macmillan, D.C., Smith, R.J., 2011. Toward a systematic approach for identifying conservation flagships. Conserv. Lett. 4, 1-8.

Wadey, J., Beyer, H.L., Saaban, S., Othman, N., Leimgruber, P., Campos-Arceiz, A., 2018. Why did the elephant cross the road? The complex response of wild elephants to a major road in Peninsular Malaysia. Biol. Conserv. 218, 91-98.

Wang, F., McShea, W.J., Wang, D., Li, S., Zhao, Q., Wang, H., Lu, Z., 2014. Evaluating landscape options for corridor restoration between Giant Panda Reserves. PLoS One 9, e105086.

Wegmann, M., Leutner, B., Dech, S., 2016. Remote sensing and GIS for ecologists: using open source software. Pelagic Publishing: Exeter, UK.

Wharton, C.H., 1968. Man, fire and wild cattle in Southeast Asia, in: Proceedings of the Annual Tall Timbers Fire Ecology Conference. pp. 7-167.

Wilson, E.O., MacArthur, R.H., 1967. The theory of island biogeography. Princeton, NJ.

Wilson, S., Davies, T.E., Hazarika, N., Zimmermann, A., 2013. Understanding spatial and temporal patterns of human-elephant conflict in Assam, India. Oryx 49, 140-149.

Zhang, L., Dong, L., Lin, L., Feng, L., Yan, F., Wang, L., Guo, X., Luo, A., 2015. Asian elephants in China: Estimating population size and evaluating habitat suitability. PLoS One $10, \mathrm{e} 0124834$.

Zhang, L., Lichao, M.A., Feng, L., 2006. New challenges facing traditional nature reserves: Asian elephant (Elephas maximus) conservation in China. Integr. Zool. 1, 179-187.

Peer) reviewing PDF | (2018:11:33037:3:0:NEW 10 Mar 2019) 
518 Zhang, L., Wang, N., Wang, Y., Ma, L., 2003. A preliminary study on the habitat and behaviors 519 of Asian elephant (Elephas maximus) in Simao, Yunnan, China. Acta Theriol. Sin. 23, 185$520 \quad 192$. 
Figure 1

The study area and distribution range of Asian elephants in China

The populations are represented by the tags of orange (Xishuangbanna-Pu'er population), blue (Cangyuan population), green (Menghai-Lancang population), and purple (Mengla-

Shangyong population).

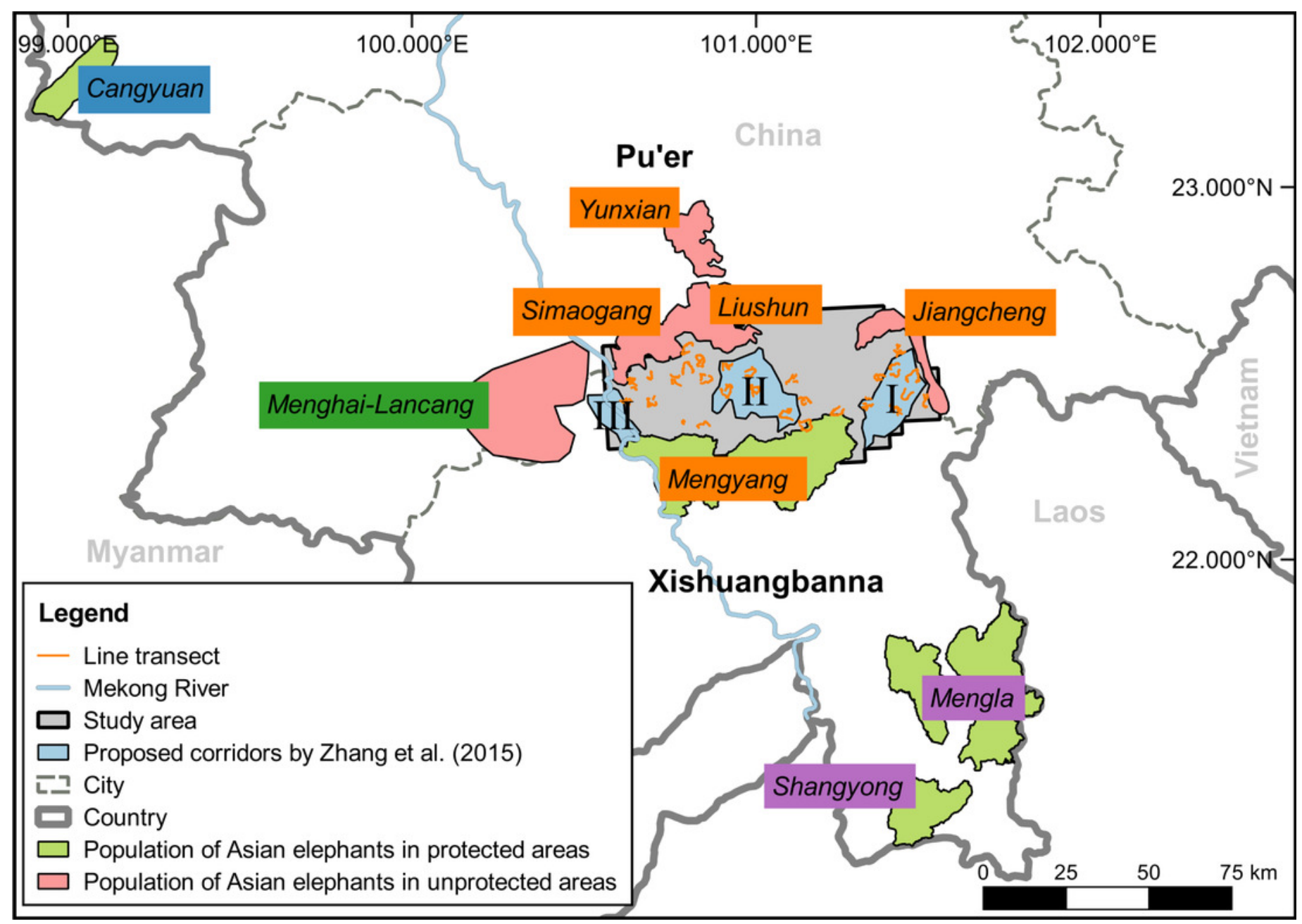


Figure 2

Habitat suitability map for Asian elephants in the study area.

The suitable habitat of Asian elephants was mainly distributed in the areas of forest matrix with multiple land-use, away from towns, and near community settlements.

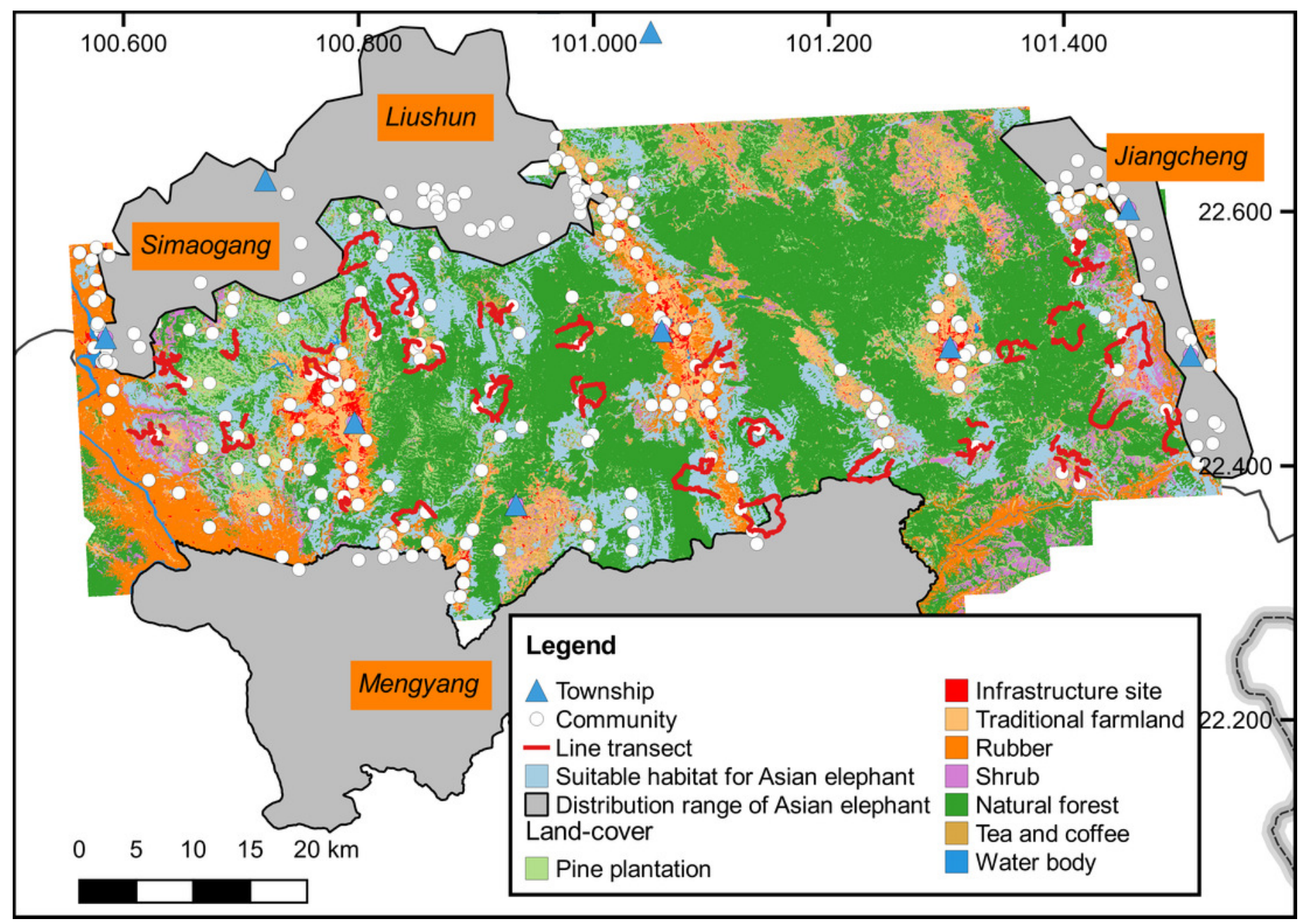




\section{Figure 3}

Habitat connectivity for Asian elephants calculated by the circuit model and the leastcost path in the study area.

The area of the white triangle is located among the subpopulations of Mengyang, Liushun, and Simaogang

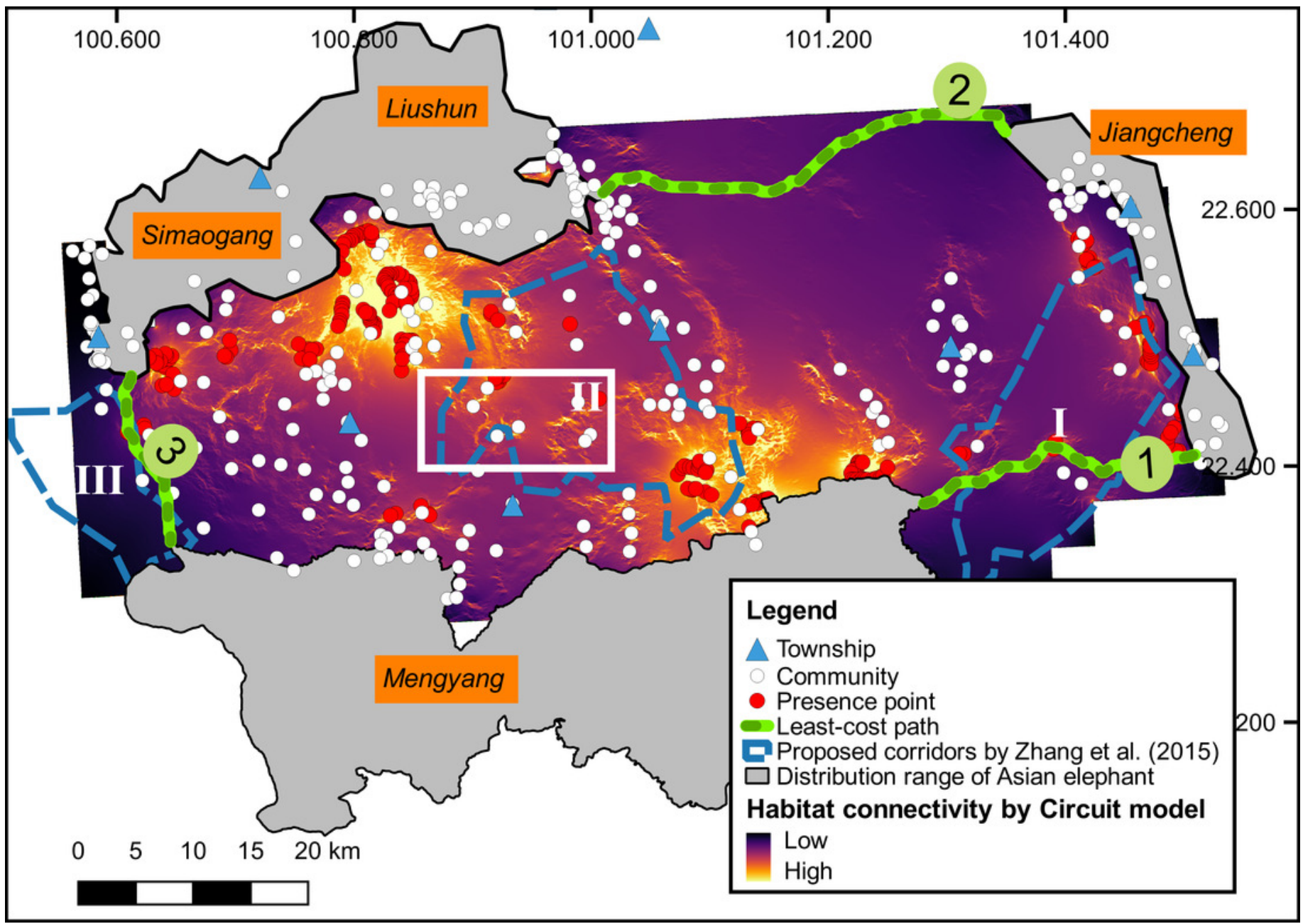




\section{Table 1 (on next page)}

Environmental variables selected in habitat suitability models for Asian elephants 
1

\begin{tabular}{|c|c|c|}
\hline Category & Variable & Data and calculation \\
\hline Geographic and & Altitude & ASTER GDEM \\
\hline topographic & Terrain roughness index & Calculated from ASTER GDEM in R \\
\hline \multirow[t]{3}{*}{ Land-cover } & $\begin{array}{l}\text { Distance to: natural forest } \\
\text { pine plantation } \\
\text { traditional farmland }\end{array}$ & Calculated by "distance" function in R \\
\hline & $\begin{array}{l}\text { Percentage of: natural forest } \\
\qquad \begin{array}{l}\text { pine plantation } \\
\text { traditional farmland }\end{array}\end{array}$ & $\begin{array}{l}\text { Calculated in Fragstats by } 1.5 \mathrm{~km} \\
\text { radius from land-cover map }\end{array}$ \\
\hline & $\begin{array}{l}\text { Edge density of: natural forest } \\
\qquad \begin{array}{r}\text { pine plantation } \\
\text { traditional farmland }\end{array}\end{array}$ & $\begin{array}{l}\text { Calculated in Fragstats by } 1.5 \mathrm{~km} \\
\text { radius from land-cover map }\end{array}$ \\
\hline Human disturbance & $\begin{array}{l}\text { Distance to: town } \\
\text { community }\end{array}$ & Calculated by "distance" function in R \\
\hline
\end{tabular}

